\title{
Influence of Fertilizers on Yields of Pineapples on a Coto Clay
}

\author{
G. Samuels, S. Alers-Alers, and G. C. Jackson ${ }^{1}$
}

\section{INTRODUCTION}

Pineapple ranks as the most important cash crop among the fruits of Puerto Rico. In 1954-55, its farm value was $\$ 2,422,000$. It ranks third in cash value as an export crop, the greater part of which is shipped to the United States for consumption as fresh or canned pineapple.

Most of the pineapples are grown in an area along the north-central coast of Puerto Rico extending westward from Vega Alta to Arecibo-a distance of about 42 miles from east to west and 16 miles from north to south (fig. 1). Almost nine-tenths of all commercial pineapples grown in Puerto Rico are produced in this area.

In 1955, the Land Authority of Puerto Rico began a program to expand the cultivation of pineapples in Puerto Rico. To stimulate this program, new growers were offered credit, technical aid, minimum price guarantees, and other facilities if they would contract to grow and deliver pineapples to the Land Authority canning factory at Manatí. This new factory has a larger capacity for canning pineapples than present acreages can provide. Thus, an expanded program of planting is needed to produce the required volume of fruit for efficient operation of this factory.

One of the principal areas now opened to new pineapple production is the zone of Camuy, Quebradillas, and Isabela. The acreage devoted to pineapples in this area was very small before 1955. Fortunately, some of the soils encountered there belong to the Espinosa, Almirante, Vega Alta, and Bayamón series, which predominate in the regular pineapple areas. However, the Coto soil series and its related Matanzas soil series, offer a large acreage of soils heretofore not normally planted to pineapples. Coto clay and sandy clay comprise an area of about 6,000 acres and the Matanzas clay an additional 1,500 acres of land suitable for growing pineapples.

\section{OBJECTIVES}

It was deemed important to obtain information on the fertilizer needs of Coto soils when growing pineapples. The Station, therefore, established a series of fertilizer experiments on Coto clay, the main soil type of the Coto series, in order to obtain such information for growers who wish to plant pineapple on these soils.

${ }^{1}$ Agronomist, Research Assistant in Agronomy, and Research Assistant in Horticulture, respectively, Agricultural Experiment Station, University of Puerto Rico, Rio, Pedras, P. R. 


\section{PROCEDURES}

Two experiments were performed: One was concerned with the quantities and number of applications needed per acre of the major fertilizer elements (nitrogen, phosphorus, and potassium); the other concerned the minorelement fertilizers, iron especially. These pineapple experiments were planted at the Isabela Substation.

Coto clay is a friable soil with excellent internal drainage, which occurs in the nearly level areas in the townships of Isabela, Quebradillas, and Camuy. The soil $\mathrm{pH}$ was 6.3. The field selected had never been planted to pineapples and was in sugarcane prior to being used for this experiment.

\section{ATLANTIC OCFAN}

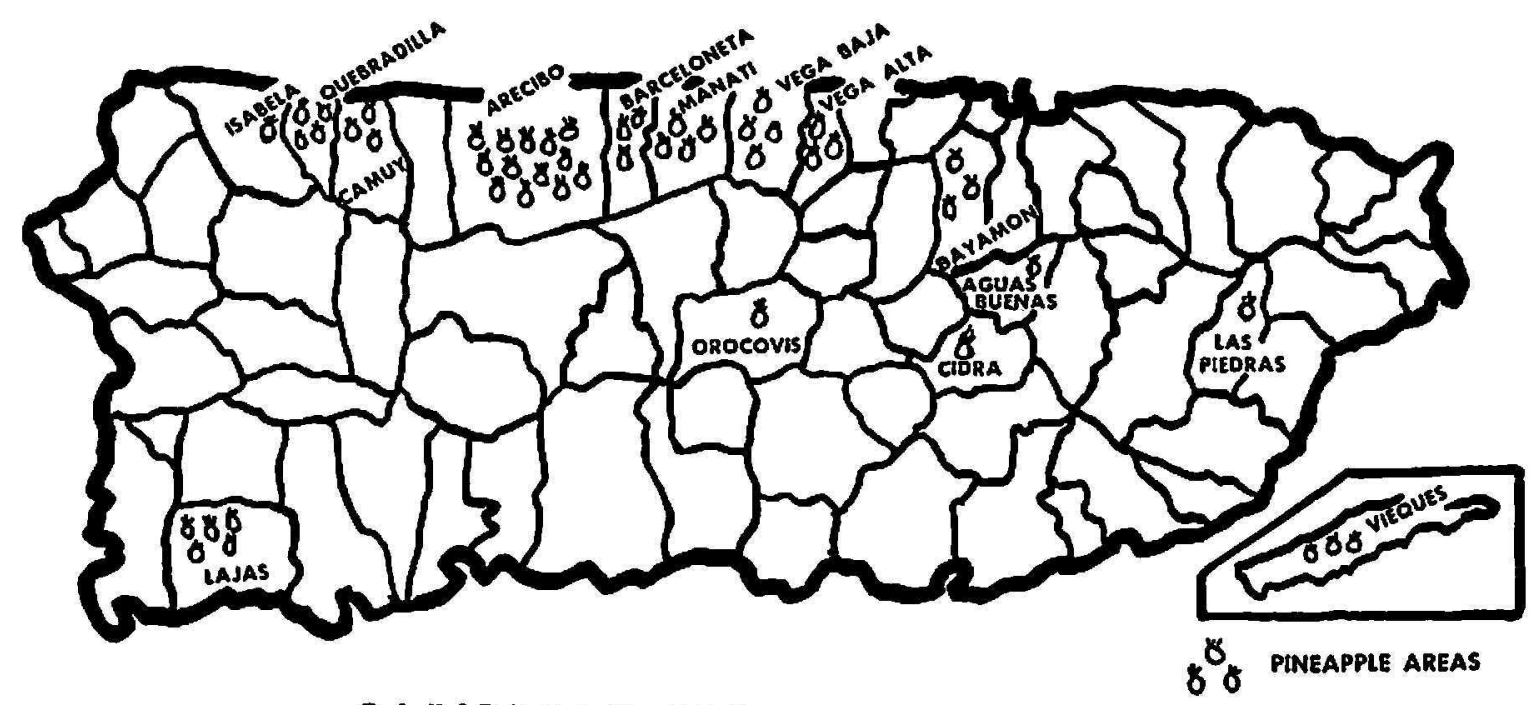

CARIBBEAN SEA

FIG. 1.-The pineapple-growing areas of Puerto Rico, 1955-56.

To control nematodes the field was injected on September 28, 1954, with DD mixture (dichloropropane and dichloropropene) at a rate of 115 pounds per acre. For the control of white grubs (Phyllophaga portoricensis), the soil was treated with Aldrin on September 14, 1954, at a rate of 4 pounds of technical Aldrin per acre.

The treatments for the major-element experiment (table 1) included seven fertilizer levels and four fertilizer applications. The experimental design was a randomized split-plot one, with the number of fertilizer applications compared in the main plots and the various fertilizer levels in the split-plots. There were six replications of each split-plot treatment. The treatments were so arranged that all plots received fertilizer at time of planting; all plots, except those labeled "one application," received another fertilizer application 4 months after planting; all plots, except those marked "one and two applications," received a third application 8 
months after planting; and only the plots marked "four fertilizer applications" received fertilizer again 12 months after planting.

The source of nitrogen used was ammonium sulfate (20-percent $N$ ), the phosphorus source was superphosphate (20-percent $\mathrm{P}_{2} \mathrm{O}_{5}$ ), and the potassium source was potassium chloride $\left(60\right.$-percent $\left.\mathrm{K}_{2} \mathrm{O}\right)$. The various components were weighed and mixed before applying in the field. For the first application the fertilizer was applied to the soil in the row below the plant. For all other applications the fertilizer was broadcast by hand near the base of the plant and the axils of the lower leaves.

TABLE 1.-Fertilizer treatments used in the pineapple experiment, Isabela Substation, 1954-56

\begin{tabular}{|c|c|c|c|c|c|c|c|c|c|c|c|c|c|c|}
\hline \multicolumn{3}{|c|}{$\begin{array}{l}\text { Fertilizer applied in } \\
\text { pounds per acre per } \\
\text { application of }\end{array}$} & \multicolumn{12}{|c|}{$\begin{array}{l}\text { Total fertilizer applied in pounds per acre for the number of fertilizer applications } \\
\text { indicated }-1\end{array}$} \\
\hline \multirow{2}{*}{$\mathbf{N}$} & \multirow{2}{*}{$\mathrm{P}_{2} \mathrm{O}_{6}$} & \multirow{2}{*}{$\mathbf{K}_{2} \mathbf{O}$} & \multicolumn{3}{|c|}{ First } & \multicolumn{3}{|c|}{ Second } & \multicolumn{3}{|c|}{ Third } & \multicolumn{3}{|c|}{ Fourth } \\
\hline & & & $\mathrm{N}$ & $\mathrm{P}=\mathrm{O}$, & $\mathbf{K}_{2} \mathbf{O}$ & $\mathbf{N}$ & $P_{2} O_{6}$ & $\mathbf{K}_{2} \mathbf{O}$ & $\mathbf{N}$ & $\mathrm{P}_{2} \mathrm{O}_{8}$ & $\mathrm{~K}_{\mathbf{2}} \mathrm{O}$ & $\mathbf{N}$ & $\mathrm{P}_{2} \mathrm{O}_{6}$ & $\mathrm{~K}_{2} \mathrm{O}$ \\
\hline 0 & 40 & 40 & 0 & 40 & 40 & 0 & 80 & 80 & 0 & 120 & 120 & 0 & 160 & 160 \\
\hline 40 & 40 & 40 & 40 & 40 & 40 & 80 & 80 & 80 & 120 & 120 & 120 & 160 & 160 & 160 \\
\hline 80 & 0 & 40 & 80 & 0 & 40 & 160 & 0 & 80 & 240 & 0 & 120 & 320 & 0 & 160 \\
\hline 80 & 20 & 40 & 80 & 20 & 40 & 160 & 40 & 80 & 240 & 60 & 120 & 320 & 80 & 160 \\
\hline 80 & 40 & 0 & 80 & 40 & 0 & 160 & 80 & 0 & 240 & 120 & 0 & 320 & 160 & 0 \\
\hline 80 & 40 & 40 & 80 & 40 & 40 & 160 & 80 & 80 & 240 & 120 & 120 & 320 & 160 & 160 \\
\hline 120 & 40 & 40 & 120 & 40 & 40 & 240 & 80 & 80 & 360 & 120 & 120 & 480 & 160 & 160 \\
\hline
\end{tabular}

1 1st fertilizer application at time of planting, 2nd fertilizer application 4 months after planting, $3 \mathrm{~d}$ fertilizer application 8 months after planting, and 4th fertilizer application 12 months after planting.

The sub- or split-plots consisted of three rows, 26 feet long. The pineapple plants were planted 18 inches apart in the rows with $11 / 2$ feet between rows and $41 / 2$ feet between plots, making a plot size of about $1 / 210$ acre in area. There were 16 plants per row, or 48 plants per plot, which corresponds to about 11,675 plants per acre. Slips of the Red Spanish variety, the main commercial pineapple variety of the Island, were planted October 28-30, 1954. The first fertilizer application was on October 24, 1954, the second on February 25, 1955, the third on June 25, 1955, and the fourth on October 25, 1955. The plants were treated with acetylene on November 14, 1955, to induce flowering. This consisted of spraying the crown of the plant with 25 to $30 \mathrm{ml}$. of a solution made by dispersing 2 ounces of calcium carbide in 5 gallons of water in a closed container.

The minor-element experiment consisted of a randomized incomplete- 
block design with 13 treatments and 4 replications. The size of plot and planting distances were the same as that for the major-fertilizer-element experiment. All treatments received a 16-8-8 fertilizer at rates equivalent to 2,000 pounds per acre, divided into four applications. Time of planting and dates of application of the fertilizer were the same as those for the other experiment. The treatments and the rates and methods of application are given in table 3 under Results.

\section{RESULTS}

MAJOR ELEMENTS

\section{Nitrogen}

Nitrogen fertilizer was of prime importance in securing high yields of pineapples in this experiment. Yields increased with increased application of nitrogen. The highest yields of 18.6 tons of pineapples per acre were obtained with 480 pounds of nitrogen per acre (table 2 ). The need of nitrogen was visible from the very start of the experiment. Those plots receiving no nitrogen showed a chlorosis even 1 month after planting. During the progress of the experiment all no- or low-nitrogen plots were light yellowgreen in color and showed poor growth. The higher nitrogen-treatment plants all had a dark-green color, large well-formed leaves, and showed good growth.

It appears that the total nitrogen applied per acre, rather than the number of applications made, was of more importance insofar as influence of nitrogen on yields was concerned. In figure 2 the quantity of nitrogen applied per acre is plotted against the yield of fruit per acre. The number of applications used to apply the nitrogen are indicated at each point. We can see many instances where the same quantity of nitrogen gave no significant difference in yield, no matter how many applications were used. For example, 240 pounds of nitrogen, when divided into two fertilizer applications, no more gave a significant difference in yield than when divided into three. Also 320 pounds of nitrogen per acre, split into four applications, produced no significantly different yield than 360 pounds in three applications. The highest yield of 18.6 tons per acre was obtained by the use of 480 pounds of nitrogen per acre split into four applications. However, the design of the experiment was such that this rate of 480 pounds of nitrogen was not applied in two or three applications. It appears that, in all probability, the use of 480 pounds per acre of nitrogen would have given as high a yield, even if fewer than the four applications had been used. As stressed before, the quantity of nitrogen applied per acre and not the number of applications appears to be a main limiting factor for high pineapple yields. 


\section{Phosphorus}

There was no significant response to phosphate fertilizers, regardless, of rate or number of applications made. The use of rates up to 160 pounds of

TABLE 2.-The yields of pineapple as influenced by various fertilizer levels and number of applications at Isabela Substation, 1954-56

\begin{tabular}{|c|c|c|c|c|c|c|c|}
\hline \multicolumn{3}{|c|}{ Treatment in pounds per acre per application of- } & \multicolumn{4}{|c|}{$\begin{array}{l}\text { Mean yjeld of pineapple per acre for } \\
\text { the number of fertilizer applications } \\
\text { indicated }\end{array}$} & \multirow{2}{*}{ Means } \\
\hline $\mathbf{N}$ & $\mathrm{P}_{2} \mathrm{O}_{6}$ & $\mathrm{~K}_{2} \mathrm{O}$ & 1 & 2 & 3 & 4 & \\
\hline \multicolumn{8}{|c|}{ Nitrogen $(N)$} \\
\hline & & & Tons & Tons & Tons & Tons & Tons \\
\hline 0 & 40 & 40 & 8.6 & 10.6 & 10.5 & 11.3 & 10.2 \\
\hline 40 & 40 & 40 & 9.1 & 10.8 & 13.2 & 13.3 & 11.4 \\
\hline 80 & 40 & 40 & 9.9 & 12.7 & 13.9 & 16.5 & 13.2 \\
\hline 120 & 40 & 40 & 10.9 & 13.0 & 15.8 & 18.6 & 14.6 \\
\hline
\end{tabular}

Phosphorus $\left(\mathrm{P}_{2} \mathrm{O}_{5}\right)$

\begin{tabular}{c|c|c|c|c|c|c|c}
\hline 80 & 0 & 40 & 10.1 & 11.4 & 13.0 & 16.2 & 12.7 \\
80 & 20 & 40 & 8.7 & 12.2 & 14.4 & 16.3 & 12.9 \\
80 & 40 & 40 & 9.9 & 12.7 & 13.9 & 16.5 & 13.2 \\
\hline & Potassium $\left(K_{2} O\right)$ \\
\hline 80 & 40 & 0 & 9.9 & 10.5 & 12.9 & 15.2 & 12.1 \\
80 & 40 & 40 & 9.9 & 12.7 & 13.9 & 16.5 & 13.2 \\
\hline
\end{tabular}

Least significant difference needed for comparisons between fertilizer treatments of same application at:

5-percent level

1-percent level

$\left|\begin{array}{l}1.85 \\ 2.50\end{array}\right|$

1.85

1.85

1.85

0.92

\begin{tabular}{l|l|l|l|l|}
2.50 & 2.50 & 2.50 & 2.50 & 1.25 \\
\hline
\end{tabular}

Least significant difference needed for comparisons between mean of all treatments per application at: 5 -percent level 1.85; 1-percent level 2.50 .

Least significant difference needed for comparisons between any fertilizer treatment at any number of applications at: 5-percent level 2.61; 1-percent level 3.42.

$\mathrm{P}_{2} \mathrm{O}_{5}$ per acre did not materially increase nor decrease yields. Previous work in Puerto Rico had shown that, for other pineapple soils, phosphate ferti- 


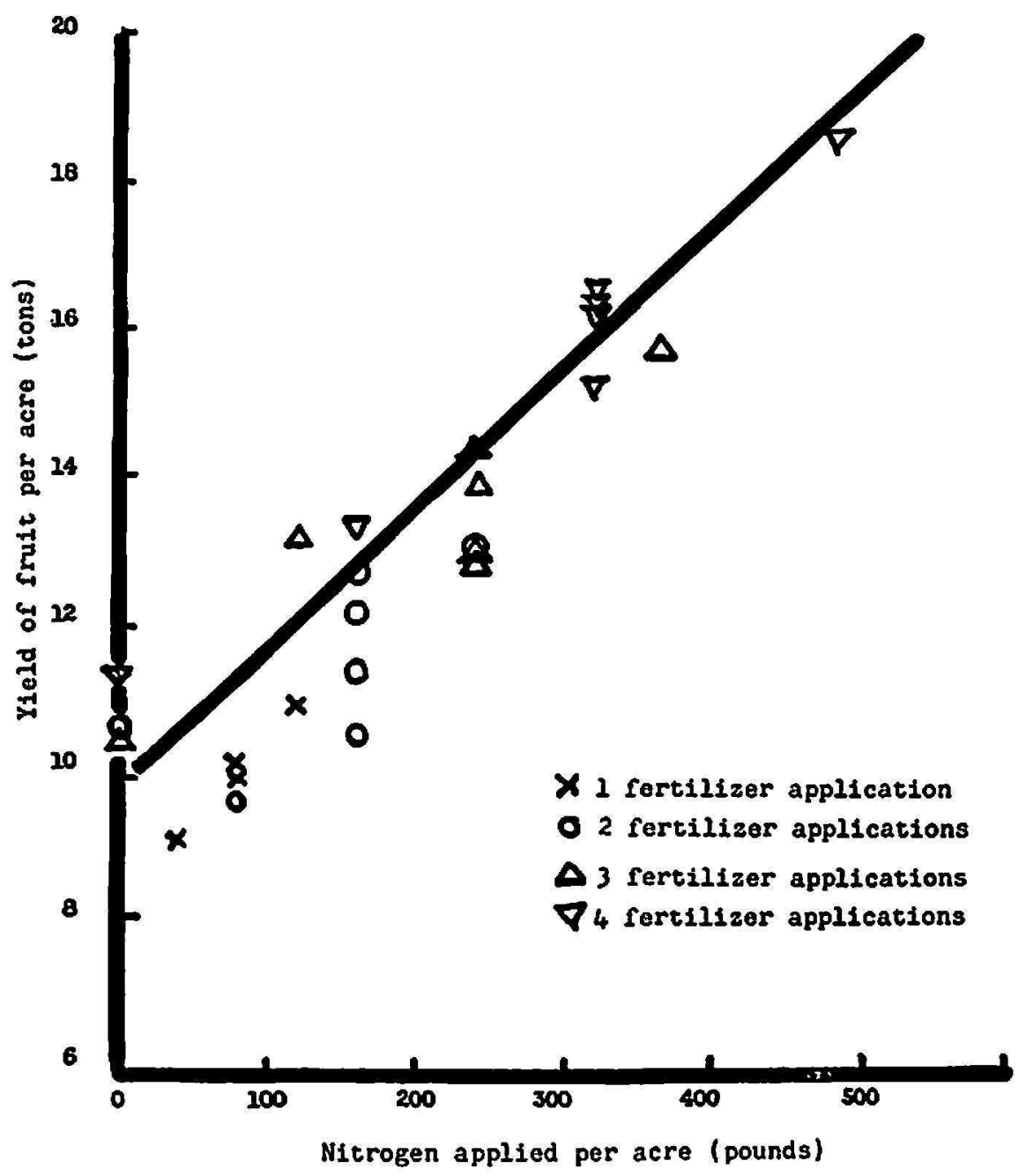

FIg. 2.-The influence of the rate at which nitrogen was applied per acre on yields of pineapples.

lizers were needed in only small quantities. Rates higher than 56 pounds $\mathrm{P}_{2} \mathrm{O}_{5}$ per acre caused a significant decrease in yields (4). ${ }^{2}$

Before undertaking these experiments with pineapples on a Coto clay, it was thought that a good response should be obtained from the use of phosphate fertilizers. This premise was based on the known fact that for sugarcane, a crop with a low phosphate requirement, significant responses have been obtained with phosphate fertilizers on Coto clay (1). The lack of response of pineapples to phosphate applications on a Coto clay appears once again to indicate that pineapples have very low phosphate needs, and to stress the undesirability of high phosphate applications for pineapples in the Coto soil series.

\section{Potassium}

A yield response was obtained from the use of potash fertilizers. Except for the second application, no significant increase was obtained, however

2 Italic numbers in parentheses refer to Literature Cited, p. 26. 
(table 2). But the mean data on the applications indicate that potash fertilizers had a significant influence in increasing yields.

It is of interest to note that responses to potash applications are not obtained for sugarcane on a Coto clay (1), whereas they are obtained with pineapples. Other pineapple soils have shown responses to potash fertilizers, and it appears that the Coto clay also requires potash applications for optimum pineapple yields.

\section{Number of Fertilizer Applications}

The number of fertilizer applications significantly influenced the yields of fruit (table 2). Yield increases were obtained with each additional fertilizer application. However, as mentioned previously, credit is due primarily to the total quantity of fertilizer applied-especially nitrogen. Thus we cannot definitely state the exact number of applications needed. Recent experiments have shown that, in soils such as the Bayamón sandy clay, the fertilizer applied in one application at time of planting is as good as several applications totaling the same amount of fertilizer. For Lares clay two to three fertilizer applications were sufficient for optimum yields.

\section{Leaf Analysis}

Leaf samples were taken to determine whether foliar diagnosis of the pineapple plant was useful as a means of determining the crop's fertilizer needs. Previous work in Puerto Rico (5), although limited to one crop, had indicated that foliar diagnosis might be practicable for pineapple.

The leaf values obtained are given in table 3 . They are lower in leaf nitrogen, phosphorus, or potassium than were obtained in previous experiments in other areas.

NITROGEN. The leaf-nitrogen values for the various applications showed a significant linear correlation with the relative yields of pineapples per acre. Although leaf-nitrogen values were somewhat lower as compared with previous leaf samples from other pineapple areas, there was a definite increase in leaf nitrogen with increasing nitrogen applications and increasing yields (table 3 ). The equations obtained relating leaf-nitrogen values $(X)$ with relative yields of fruits per acre $(Y)$ for the three fertilizer applications were:

$$
\begin{aligned}
& Y=265.7 X-38.5 \text { (1 application, leaf sample at } 4 \text { months }) \\
& Y=66.9 X+53.4 \text { (2 applications, leaf sample at } 8 \text { months }) \\
& Y=118.7 X-37.2 \text { (3 applications, leaf sample at } 12 \text { months) }
\end{aligned}
$$

The resultant equations were all highly significant. The coefficient of determination, or prediction value $\left(r^{2} \times 100\right)$, for these equations averaged 
98.6 percent. That is to say, 98.6 percent of the variation of leaf nitrogen related to relative yields of fruit was explainable by these equations.

Although there were significant correlations between leaf nitrogen and yields for each individual fertilizer application, the leaf-nitrogen values increased with each sampling after each application. Thus we find that leaf-nitrogen values of $0.52,0.80$, and 1.16 percent were all associated with

TABLE 3.-Nutrient content of pineapple leaves from plant crop at Isabela Substation, 1954-66

\begin{tabular}{|c|c|c|c|c|c|c|c|c|}
\hline \multicolumn{3}{|c|}{$\begin{array}{l}\text { Treatment in pounds per acre per } \\
\text { application of- }\end{array}$} & \multicolumn{3}{|c|}{$\begin{array}{l}\text { Nutrient content of pineapple leaves, } \\
\text { dry-weight basis, for number of fertilizer } \\
\text { applications indicated }\end{array}$} & \multicolumn{3}{|c|}{$\begin{array}{l}\text { Relative yields of pineapples } \\
\text { per acre for number of fertilizer } \\
\text { applications indicated }\end{array}$} \\
\hline $\mathbf{N}$ & $\mathrm{P}_{2} \mathrm{O}_{6}$ & $\mathrm{~K}_{2} \mathrm{O}$ & 11 & $2^{2}$ & 38 & 1 & 2 & 3 \\
\hline \multicolumn{9}{|c|}{ Nitrogen } \\
\hline & & & Percent & Percent & Percent & & & \\
\hline 0 & 40 & 40 & 0.44 & 0.51 & 0.91 & 79 & 82 & 67 \\
\hline 40 & 40 & 40 & .46 & .57 & .98 & 84 & 83 & 84 \\
\hline 80 & 40 & 40 & .48 & .76 & 1.08 & 91 & 98 & 88 \\
\hline 120 & 40 & 40 & .52 & .80 & 1.16 & 100 & 100 & 100 \\
\hline
\end{tabular}

Phosphorus

\begin{tabular}{r|r|r|r|r|r|r|r|r}
\hline 80 & 0 & 40 & 0.07 & 0.09 & 0.12 & 101 & 90 & 94 \\
80 & 20 & 40 & .03 & .09 & .13 & 88 & 96 & 104 \\
80 & 40 & 40 & .05 & .09 & .15 & 100 & 100 & 100 \\
\hline
\end{tabular}

Potassium

\begin{tabular}{r|r|r|r|r|r|r|r|r}
\hline 80 & 40 & 0 & 2.93 & 2.18 & 2.40 & 100 & 91 & 94 \\
80 & 40 & 40 & 3.13 & 3.06 & 2.70 & 100 & 100 & 100 \\
\hline
\end{tabular}

1 Leaf sample taken 4 months after planting.

2 Leaf sample taken 8 months after planting.

${ }^{3}$ Leaf sample taken 12 months after planting.

a relative yield of 100 for each particular fertilizer application (table 3). Since each successive fertilizer application meant that more nitrogen was being applied, we should expect increased leaf-nitrogen values and increased yields of fruit. It was felt that a more comprehensive picture could be obtained if the relative yield calculations for nitrogen were utilized as a basis of 100 , the highest yield obtained with the largest nitrogen application. Therefore, 18.6 tons of pineapples obtained with 480 pounds of nitrogen was assigned a relative yield of 100 , and the relative yields for the other nitrogen treatments were then calculated and associated with their leaf-nitrogen 
values. The resultant equation obtained was $Y=42.9 X+32.8$, and it was highly significant, having a prediction value of 92 percent. This equation covers the entire range of yields obtained from the various rates and number of applications of nitrogen (fig. 3 ).

It is interesting to note that leaf-nitrogen and relative yield values from a previous pineapple fertilizer experiment at Corozal on a Lares clay (5), when plotted, came close to the equation found for this experiment on Coto

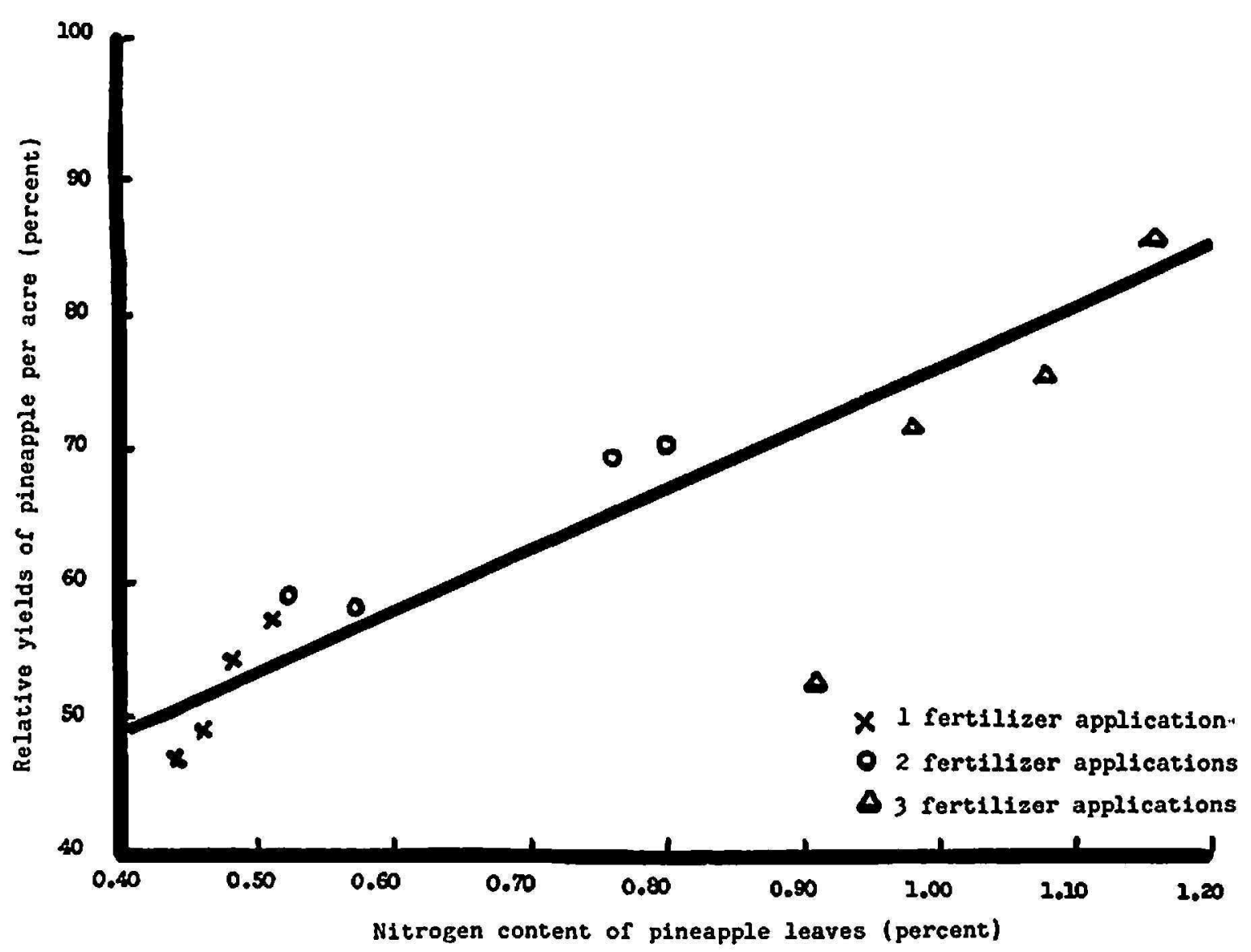

FIG. 3.-The relationship between the leaf-nitrogen content of Red Spanish pineapples and relative yields of fruit per acre for various numbers of fertilizer applications.

clay. For the Corozal experiment a relative yield of 100 was associated with a leaf-nitrogen value of 1.66 percent; for the Coto clay, using the equation $Y=42.9 X+32.8$, a relative yield of 100 was linked to a leaf-nitrogen value of 1.57 percent.

Aside from the question of the most suitable tissue for leaf analysis in pineapple, we should ascertain the best time to take leaf samples. Previous work on sugarcane $(3)$ has indicated that leaf samples taken at a cane age of 3 months best indicated differences in the nitrogen status of the plant and gave the highest correlations with yields. As shown in figure 4, the differences in leaf nitrogen attributable to the fertilizer applied were best 
displayed 4 months after fertilizing. At 2 months after an application, the fertilizer had not been adequately absorbed by the plant for all treatments; and at 8 and 12 months, differences caused by treatments had diminished greatly or disappeared.

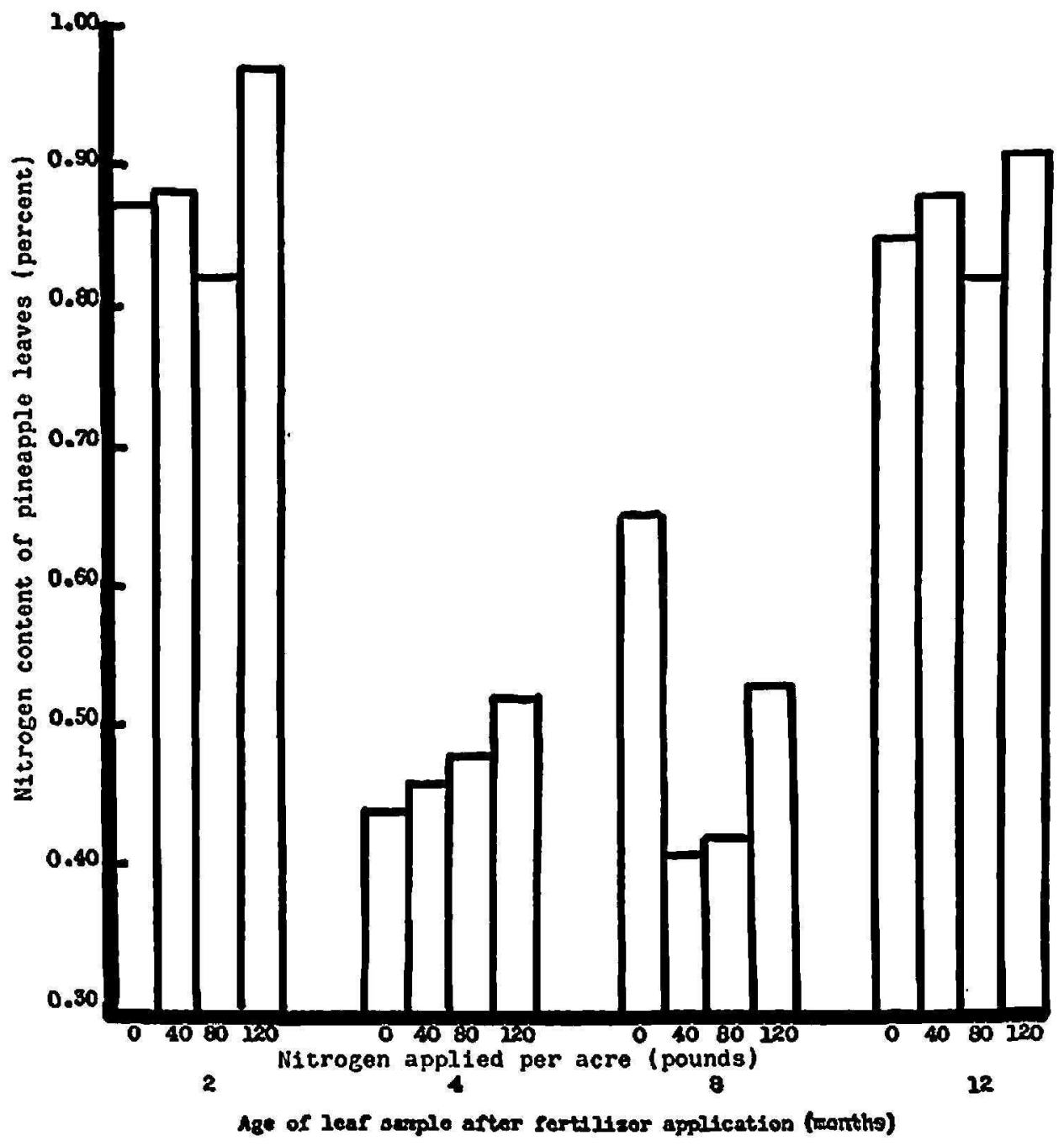

FrG. 4.-The influence of the age of the leaf sample after fertilizer application on the nitrogen content of the pineapple leaf.

PHOSPHORUS. Leaf-phosphorus values showed no significant relationship with pineapple yields. Inasmuch as phosphate fertilizers did not influence yields, we can suppose that the leaf values obtained were for optimum levels. For a Lares clay, a leaf-phosphorus level of 0.17 percent (5) was found to be a safe minimum for good pineapple yields. The values obtained for this experiment indicate that leaf-phosphorus levels as low as 0.09 percent were adequate on a Coto clay.

POTASSIUM. There was a significant linear relationship between leaf potassium and relative yields of pineapples per acre. The leaf values for potassium were all lower than those obtained at Corozal (5) which ranged 
above 4 percent. For the Coto clay, leaf-potassium values near 3 percent were associated with the optimum yields of fruit.

\section{MINOR ELEMENTS}

Iron

The yields of pineapple were increased significantly by the use of ferrous sulfate sprays. The yield increase obtained was 1.4 tons of pineapples per

TABLE 4.-Yields of pineapples from minor-element fertilizer experiment at Isabela Substation, 1956

\begin{tabular}{|c|c|c|c|c|c|}
\hline $\begin{array}{l}\text { Treatment } \\
\text { No. }\end{array}$ & Treatment ${ }^{t}$ & $\begin{array}{l}\text { Rate of applica- } \\
\text { tion per acre }\end{array}$ & $\begin{array}{l}\text { Number of } \\
\text { applications }\end{array}$ & $\begin{array}{l}\text { Method of } \\
\text { Application }\end{array}$ & $\begin{array}{c}\text { Yield of } \\
\text { pineapples } \\
\text { per acre }\end{array}$ \\
\hline $\begin{array}{l}1 \\
2 \\
3 \\
4 \\
5 \\
6 \\
7 \\
8 \\
9\end{array}$ & $\begin{array}{l}\text { Control } \\
\text { FeSO }_{4} \\
\text { Fe-EDTA } \\
\text { Fe-EDTA on vermiculite } \\
\text { FTE4 }^{3} \\
\mathrm{NU}^{3} \mathrm{IRON}^{6} \\
\mathrm{MgO}^{6} \\
\mathrm{ZnSO}_{4}{ }^{8}\end{array}$ & $\begin{array}{l}\text { Pounds } \\
0 \\
12^{7} \\
2^{7} \\
40 \\
100 \\
3^{7} \\
300 \\
50\end{array}$ & $\begin{array}{l}0 \\
4 \\
4 \\
1 \\
1 \\
4 \\
1 \\
1\end{array}$ & $\begin{array}{l}\text { None } \\
\text { Spray } \\
\text { do. } \\
\text { Soil } \\
\text { do. } \\
\text { Spray } \\
\text { Soil } \\
\text { do. }\end{array}$ & $\begin{array}{l}\text { Tons } \\
16.0 \\
17.4 \\
17.2 \\
16.4 \\
17.1 \\
17.0 \\
17.4 \\
16.9\end{array}$ \\
\hline
\end{tabular}

Least significant difference needed between treatments at: 5 -percent level 1.40.

1 All treatments received $2,000 \mathrm{lb}$. of a 16-8-8 fertilizer per acre in 4 applications.

${ }^{2}$ A sodium ferric ethylenediamine tetra-acetate (12-percent $\mathrm{Fe}$ ); Sequestrene $\mathrm{NaFe}$.

${ }^{3}$ Fe-EDTA absorbed on vermiculite (6-percent $\mathrm{Fe}$ ).

${ }^{4}$ A relatively insoluble powdered glass containing $\mathrm{Mn}, \mathrm{Fe}, \mathrm{Zn}, \mathrm{Cu}, \mathrm{B}$, and $\mathrm{Mo}$.

${ }^{5} \mathrm{~A}$ commercial preparation of iron malonate (30-percent $\mathrm{Fe}$ ).

6 Also received treatment No. 2.

${ }^{7}$ Dissolved in 100 gal. water.

acre, or 9 percent more than when no iron was applied (table 4). A total of four spray applications as applied at 2-month intervals beginning when the plants were 2 months old. The rate used was 12 pounds of ferrous sulfate $\left(\mathrm{FeSO}_{4} \cdot 7 \mathrm{H}_{2} \mathrm{O}\right)$ in 100 gallons of water per acre.

It is a common practice for growers to use ferrous sulfate as the source of iron to control iron chlorosis in pineapple. The results obtained here indicate that the Coto clay needs iron sprays for best growth of pineapples, as do the other pineapple soils of Puerto Rico.

A new source of iron, chelated iron, has been used successfully in treating iron deficiencies in citrus and ornamental plants (6). Chelated iron is 
composed of a complex organic salt usually combined with the metallic iron. The extremely stable compound fixes the metallic iron added and keeps it soluble so that it can be absorbed readily by the root system or leaves of the growing plant or tree. The chelates were tried in both soil and spray applications, and they did not give responses better than or equal to those produced by the regularly used ferrous sulfate (see table 4).

The use of the chelated iron as a spray at the rate recommended by the manufacturer-2 pounds per acre-was slightly inferior to ferrous sulfate in increasing yields. Inasmuch as chelated iron costs about 8 to 10 times as much as ferrous sulfate, there appears to be no advantage at present for its use by the farmer as an iron source for pineapples during the first year of the crop. Chelated iron does have one special advantage in that it can be used in spray form without harm when the plants are fruiting, whereas ferrous sulfate will burn the fruit.

Iron malonate (commercially known as NU-IRON) containing 30-percent iron when applied as a spray was also unsuccessful in increasing yields of pineapples significantly (table 4).

Spraying with iron salts involves an expense that could be reduced if the iron could be applied as a soil application. Inorganic iron salts much as ferrous sulfate become readily fixed in the soil and do not provide sufficient iron to the plant. The use of chelated iron in a soil application was believed to be a possible means of providing the needed iron to the plant. However, the data show that chelated iron, when added to the soil at the rate of 40 pounds per acre, did not give as good a control of iron chlorosis as ferrous sulfate sprays.

Another source used for adding iron as well as other mineral elements to the soil was fritted trace elements (FTE). This agricultural "frit" is basically a glass which is relatively insoluble, but which supplies traces of minor elements to growing plants. It is made by heating the various minor elements with a ceramic-making material at a very high temperature, and the resultant molten mass is allowed to flow into cold running water where it is fragmented into many small pieces. The process is known as "fritting", and the resultant product is "frit". This agricultured frit has proved to be an economical means of supplying minor elements slowly over a period of a few years ( $(7)$.

The results obtained indicate that FTE does not increase yields as much as the ferrous sulfate sprays. However, the difference obtained between the two treatments was very small (table 4 ). The present price of the frit is about the same as that of ferrous sulfate per pound, but when used at recommended rates, about twice as much FTE as ferrous sulfate was required per acre. However, from the standpoint of economy of application, the frit, which need be applied only once, is more economical to use than 
the ferrous sulfate sprays. Another economical advantage yet to be determined is whether the frit produces sufficient iron for the ratoon crops. If so, then FTE offers a definite economical advantage as a source of iron for pineapples as compared to chelates and ferrous sulfate sprays.

\section{Magnesium}

The pineapples showed no significant response to magnesium applications. The use of 300 pounds per acre of magnesium oxide did not increase yields over those receiving none (treatment 7 minus treatment 2, table 4). The plants not treated with magnesium oxide did not display any visual deficiency symptoms. Visual symptoms of magnesium deficiency on pineapples has been detected recently on pineapples growing on the Bayamón sandy clay in areas near Manatí.

\section{Zinc}

The addition of zinc sulfate to the soil at a rate of 50 pounds per acre failed to increase pineapple yields (treatment 8 minus treatment 2, table 4). Landrau and Samuels reported no responses were obtained with zinc sulfate on a Bayamón sandy clay (2).

\section{SUMMARY}

This paper reports the results obtained in studies carried out on Red Spanish pineapples to determine their major- and minor-element fertilizer requirements for Coto clay soils. The experimental results may be summarized as follows:

1. Nitrogen was of prime importance in securing maximum yields of pineapples. The use of 480 pounds of nitrogen per acre gave the highest yields.

2. There was no significant response to phosphate fertilizers.

3. Yield responses were obtained from the use of potash fertilizers.

4. The number of fertilizer applications significantly influenced the yield of fruit; however, credit was due mainly to the total fertilizer applied-especially nitrogen.

5. The leaf analyses obtained were lower in nitrogen, phosphorus, and potassium than for other experiments.

6. Leaf-nitrogen values showed a significant correlation with relative yield of pineapples.

7. For Coto clay, leaf-phosphorus values of 0.09 percent and leaf-potassium values of 3 percent were associated with optimum yields of fruit.

8. The yields of pineapples were increased by the use of ferrous sulfate sprays.

9. Chelated iron as a spray or in soil applications gave no better results in increasing yields than ferrous sulfate sprays. 
10. Iron malonate applied as a spray was unsuccessful in increasing pineapple yields.

11. The use of a glass frit containing iron and other minor elements held in a relatively slowly soluble form gave yields similar to the use of the ferrous sulfate sprays, but at a lower cost per acre.

12. Magnesium oxide and zinc sulfate did not increase yields on a Coto clay.

\section{RESUMEN}

Este trabajo informa los resultados obtenidos en estudios llevados a cabo en siembras de piña de la variedad Española Roja en suelos Coto arcillosos para determinar sus requisitor de abonamiento en cuanto a los elementos mayores y menores.

Los resultados experimentales pueden resumirse como sigue:

1. El nitrógeno tuvo primordial importancia en la producción de los más altos rendimientos de frutas. La aplicación de 480 libras de nitrógeno por cuerda produjo los rendimientos mayores.

2. No hubo una respuesta significativa a las aplicaciones de abono con fósforo.

3. Se obtuvo rendimientos satisfactorios con el uso de abonos potásicos.

4. El número de aplicaciones de abono influyó significativamente en los rendimientos. Sin embargo, por ésto se le da crédito mayormente a la cantidad total de abono aplicado, especialmente al nitrógeno.

5. Los análisis foliares efectuados demostraron valores más bajos de nitrógeno, fósforo y potasio, al compararse con otros experimentos.

6. Los valores de nitrógeno en la hoja demostraron una correlación significativa con los rendimientos relativos.

7. En los terrenos Coto arcillosos, los valores de 0.09 por ciento de fósforo en la hoja y de 3 por ciento de potasio en la hoja se asociaron con los mejores rendimientos.

8. Los rendimientos aumentaron cuando se hicieron aspersiones de sulfato de hierro.

9. Ni las aspersiones a las hojas ni las aplicaciones al terreno, de hierro chelado, produjeron un mayor aumento de los rendimientos que el producido por las aspersiones de sulfato de hierro.

10. Las aspersiones de malonato de hierro no lograron aumentar los rendimientos.

11. El uso de un compuesto especial conteniendo hierro y otros elementos menores, integrado en forma que eventualmente pudiera disolverse muy gradualmente, dió resultados similares a las aspersiones con el sulfato ferroso, pero a un costo menor por cuerda.

12. El óxido de magnesio y el sulfato de zinc resultaron inefectivos para aumentar los rendimientos en los terrenos Coto arcillosos. 


\section{LITERATURE CITED}

1. Landrau, P., Jr., and Samuels, G., Response of four sugarcane varieties to fertilizers during the first Isabela cycle, 1946-51, J. Agr. Univ. P.R. 38 (2) 73-95, 1954.

2. Landrau, P., Jr., and Samuels, G., Results of lime and minor-element fertilizer research in Puerto Rico, 1945-50, J. Agr. Univ. P.R. 40 (4) 224-34, 1956.

3. Samuels, G., and Capó, B. G., Effects of level of a fertilizer element on the uptake and concentration of that element and other elements in a plant, Agron. J. 44 (7) 352-7, 1952.

4. Samuels, G., Landrau, P., Jr., and Alers Alers, S., Influence of phosphate fertilizers on pineapple yields, J. Agr. Univ. P.R., 40 (4) 218-23, 1956.

5. Samuels, G., Landrau, P., Jr., and Olivencia, R., Response of pineapples to the application of fertilizers, J. Agr. Univ. P.R. 39 (1) 1-11, 1955.

6. Wallace, A., North, C. P., Kofranek, A. M., and Lunt, O. R., Chlorosis in ornamentals, Calif. Agr. 7 (10) 13-4, 1953.

7. Walters, E. I., Agricultural fruit, Farm Chemicals 115 (8) 30-4, 1952. 